\title{
Impact of commercial bank internal governance mechanism on credit risk: an empirical study based on China's listed banks
}

\author{
Mingwei Zhou*, Changmei Xiong
}

School of Economic and Management in Nanjing University of Science and Technology, China

*Corresponding author: Mingwei Zhou, Associate Professor, zhoumw@163.com

\begin{abstract}
This paper systematically examines the impact of the internal governance mechanism of commercial banks on credit risk from the perspective of corporate governance of commercial banks. The results show that the proportion of the largest shareholder, the proportion of the state-owned shares, the nature of the largest shareholder are significant positively correlated to credit risk; the proportion of the independent directors, the size of the board of supervisors, executive compensation, management shareholdings are significant negatively correlated to credit risk; the relationship between the size of the board and the credit risk is not significant. Based on these empirical results, this paper puts forward some related policy recommendations.
\end{abstract}

Key words: commercial bank; internal governance; credit risk; empirical analysis

\section{Introduction}

According to the relevant data, the credit risk, market risk and liquidity risk accounted for $81.3 \%, 53.8 \%$ and $36.6 \%$ respectively in the banking risk management work in 2016. Among them, the credit risk is significantly higher than other risk categories. What's more, subject to macroeconomic impact, the current quality of China's commercial banks is facing a new round of bad pressure. At present, although the non-performing loan ratio (NPL ratio) of China's banking system is still in the low of global banks. But in the future, along with our country to the production capacity, to leverage, to accelerate the process of inventory, it is possible to form a pressure on the quality of bank credit assets from multiple aspects. Based on the importance of credit risk of commercial banks, most scholars focused on the measurement of credit risk and proposed KMV model, Credit Metrics model and other modern model of credit risk measurement. However, these models apply to the more developed countries and regions in the financial market, China is still using the credit rating method of five classification. Therefore, this paper turns to research on the influencing factors of credit risk of commercial banks. 


\section{Literature review}

In recent years, domestic and foreign scholars on the commercial bank credit risk research gradually transferred to the internal governance mechanism of commercial banks. Ronald C. Anderson and Donald R. Fraser ${ }^{1}(2000)$ explored the governance structure of the Bank of Japan from 1977 to 1996 and concluded that its irrational governance structure was one of the important causes of Japan's banking restructuring. When we talk about the impact of commercial banks internal governance mechanisms on credit risk, first of all, in the equity structure of commercial banks on the impact of credit risk, the current literature is mainly from the equity concentration and equity nature of the two aspects of research. Liang Hongbo and Liu Yuanliang ${ }^{2}(2012)$ proved that the equity structure is an important factor affecting the credit risk of commercial banks. However, in the existing research, the impact of the equity structure on the credit risk of commercial banks has not reached a consensus conclusion. LaPorta et al. ${ }^{3}(2002)$, Arshad Hasan and Safilar Ali Butt ${ }^{4}(2009)$ through empirical studies, confirmed positive correlation between equity concentration degree and bank credit risk. While the view of "corporate cybernetics" argues that the concentration of equity and commercial bank credit risk was negatively correlated. In addition, there is also controversy between the nature of the state-owned shares and the controlling shareholder. Bonin et al. ${ }^{5}$ (2005) argued that the higher the proportion of state-owned shares, the greater the bank's credit risk. While some scholars considered that there was a significant negative correlation between state-owned controlling shareholders and bank credit risk.

Secondly, besides the equity structure, there are many scholars who have explored the influence of the internal governance mechanism such as board of directors and supervisors governance and executive incentive mechanism on the credit risk of commercial banks. Li Yanhong and He Ganhua ${ }^{6}(2009)$ studied the relationship between corporate governance and risk control in commercial banks from various aspects of corporate governance, and considered that the smaller size of the board of directors, the moderated supervision of the board of supervisors and the effective management incentive were conducive to strengthening bank risk management. It can be seen that the impact of internal governance on credit risk of commercial banks is not yet conclusive in academia and more theoretical and empirical analysis is needed in the future to test.

\section{Research design}

\subsection{Samples and data sources}

This paper selected 16 listed banks in China, including Bank of China, Industrial and Commercial Bank, Bank of Communications, Construction Bank, Agricultural Bank, Ping An Bank, Shanghai Pudong Development Bank, Minsheng Bank, China Merchants Bank, Huaxia Bank, Industrial Bank, CITIC Bank, Everbright Bank, Bank of Nanjing, Bank of Ningbo and Bank of Beijing for the study of samples, to analyze the impact of commercial banks internal governance on credit risk. The time span of this paper is from 2010 to 2015, so the annual 
report of 96 listed banks with full and effective information is selected. Which the vast majority of financial data were chose from the RESSET database and the CSMAR database, other data from the banks of the annual report.

\subsection{Research variables}

This paper chooses the non-performing loan ratio (NPL ratio) as the measure of credit risk for explained variables. The explanatory variables include variables about equity structure, board of directors and supervisors and executive incentive mechanism of banks. And the specific definitions of the relevant variables are shown in Table 1:

Table 1 - Major variables design and description

\begin{tabular}{|c|c|c|c|}
\hline Variable type & Variable name & Variable symbol & Variable definition \\
\hline $\begin{array}{l}\text { Explained } \\
\text { variable }\end{array}$ & $\begin{array}{l}\text { Non-performing loan } \\
\quad \text { ratio }\end{array}$ & NPL & $\begin{array}{l}\text { Balance of non-performing loans at the end of the } \\
\text { period/Balance of loans at the end of the period }\end{array}$ \\
\hline \multirow{9}{*}{$\begin{array}{l}\text { Explanatory } \\
\text { variables }\end{array}$} & $\begin{array}{l}\text { The proportion of the } \\
\text { largest shareholder }\end{array}$ & OC1 & $\begin{array}{l}\text { The ratio of the number of shares held by the } \\
\text { largest shareholder to the total number of shares }\end{array}$ \\
\hline & Equity balance degree & ZI & $\begin{array}{l}\text { The proportion of the largest shareholder } \\
\text { holdings/The proportion of the second largest } \\
\text { shareholder holdings }\end{array}$ \\
\hline & $\begin{array}{l}\text { Proportion of state - } \\
\text { owned shares }\end{array}$ & SS & The proportion of state-owned shares to all shares \\
\hline & $\begin{array}{l}\text { The nature of the largest } \\
\text { shareholder }\end{array}$ & $\mathrm{XZ1}$ & $\begin{array}{l}\text { Dummy variable, the largest shareholder is the } \\
\text { state-owned property value is } 1 \text {, otherwise takes } 0\end{array}$ \\
\hline & Board size & $\mathrm{DN}$ & Number of the board of directors \\
\hline & $\begin{array}{l}\text { Proportion of independent } \\
\text { directors } \\
\end{array}$ & ID & $\begin{array}{l}\text { The proportion of independent directors to the } \\
\text { number of board members }\end{array}$ \\
\hline & $\begin{array}{l}\text { The size of the board of } \\
\text { supervisors }\end{array}$ & SN & Number of the board of supervisors \\
\hline & Executive compensation & $\mathrm{RE}$ & The top three executives' average salaries \\
\hline & $\begin{array}{l}\text { Management } \\
\text { shareholdings }\end{array}$ & NM & $\begin{array}{l}\text { Dummy variables, the management holding takes } \\
1 \text {, Otherwise takes } 0\end{array}$ \\
\hline \multirow{2}{*}{$\begin{array}{l}\text { Control } \\
\text { variables }\end{array}$} & Capital strength & CAP & Capital adequacy ratio \\
\hline & Profitability & ROA & The ratio of return on total assets \\
\hline
\end{tabular}

\subsection{Research methods and model construction}

In view of the many advantages of the panel data model and the previous scholars' research, this paper uses the panel data model for empirical test. So as not to appear multiple collinearity problems, before constructing the model, the correlation between the explanatory variables is checked first. In order to avoid the high correlation between the variables at the same time appear in the model. The following four equations are chosen as the panel regression model: 
Model 1: $N P L_{i t}=C+\beta_{1} O C 1_{i t}+\beta_{2} D N_{i t}+\beta_{3} N M_{i t}+\beta_{4} C A P_{i t}+\beta_{5} R O A_{i t}+\varepsilon_{i t}$

Model 2: $N P L_{i t}=C+\beta_{1} Z I_{i t}+\beta_{2} I D_{i t}+\beta_{3} C A P_{i t}+\beta_{4} R O A_{i t}+\varepsilon_{i t}$

Model 3: $N P L_{i t}=C+\beta_{1} S S_{i t}+\beta_{2} R E_{i t}+\beta_{3} C A P_{i t}+\beta_{4} R O A_{i t}+\varepsilon_{i t}$

Model 4: $N P L_{i t}=C+\beta_{1} X Z 1_{i t}+\beta_{2} S N_{i t}+\beta_{3} C A P_{i t}+\beta_{4} R O A_{i t}+\varepsilon_{i t}$

Where $C$ is the intercept term, it is the relevant data of the commercial bank $i$ at time $t, \beta$ is the unknown coefficient of each explanatory variable, and $\varepsilon$ is the random disturbance term.

\section{Empirical analysis}

The empirical results of the relationship between the internal governance mechanism and the credit risk of the listed commercial banks are shown in Table 2:

Table 2 - Impact of commercial bank internal governance mechanism on credit risk

\begin{tabular}{|c|c|c|c|c|}
\hline \multirow{2}{*}{ Variables } & \multicolumn{4}{|c|}{ NPL ratio } \\
\hline & Model 1 & Model 2 & Model 3 & Model 4 \\
\hline \multirow{2}{*}{$\mathrm{C}$} & 0.0056 & $0.0146 * * *$ & $0.0565 * * *$ & $0.0168 * * *$ \\
\hline & $(0.8750)$ & (4.2029) & (4.9722) & (3.3707) \\
\hline \multirow{2}{*}{ OC1 } & $0.0046^{* *}$ & & & \\
\hline & $(2.3560)$ & & & \\
\hline \multirow{2}{*}{ ZI } & & -0.0003 & & \\
\hline & & $(-1.4360)$ & & \\
\hline \multirow{2}{*}{ SS } & & & $0.0035^{*}$ & \\
\hline & & & (1.7636) & \\
\hline \multirow{2}{*}{ XZ1 } & & & & $0.0016^{* *}$ \\
\hline & & & & (2.0658) \\
\hline \multirow{2}{*}{ DN } & 0.0010 & & & \\
\hline & $(0.5766)$ & & & \\
\hline \multirow{2}{*}{ ID } & & $-0.0187 * * *$ & & \\
\hline & & $(-5.7173)$ & & \\
\hline \multirow{2}{*}{ SN } & & & & $-0.0024 * *$ \\
\hline & & & & $(-2.2665)$ \\
\hline \multirow{2}{*}{ RE } & & & $-0.0027 * * *$ & \\
\hline & & & $(-4.5535)$ & \\
\hline \multirow{2}{*}{ NM } & $-0.0027^{* *}$ & & & \\
\hline & $(-2.3626)$ & & & \\
\hline \multirow{2}{*}{ CAP } & $0.0640 * *$ & $0.0828 * * *$ & -0.0023 & 0.0211 \\
\hline & (2.3191) & (3.1788) & $(-0.0808)$ & $(0.7233)$ \\
\hline \multirow{2}{*}{ ROA } & $-0.6658 * * *$ & $-0.7899 * * *$ & -0.2982 & $-0.4236 *$ \\
\hline & $(-2.7712)$ & $(-3.7614)$ & $(-1.4285)$ & $(-1.8884)$ \\
\hline R-squared & 0.1662 & 0.3111 & 0.2631 & 0.1383 \\
\hline Obs & 96 & 96 & 96 & 96 \\
\hline
\end{tabular}


According to the regression results, the four equations $\mathrm{F}$ statistic and $\mathrm{T}$ statistic have passed the significance test, indicating that the explanatory variable is better able to explain the NPL ratio. Firstly, the result of the proportion of the largest shareholder (OC1)can be seen from the Model 1. The regression coefficient was significantly positive. That is, the higher the proportion of the largest shareholder, the higher the NPL ratio. While the equity balance degree (ZI) regression coefficient was not significant in Model 2. Secondly, in terms of the equity nature, according to the proportion of state-owned shares (SS) regression results in Model 3, the regression coefficient was significant positive correlation. That is to reduce the proportion of state-owned shares of commercial banks, help to reduce credit risk.

Thirdly, from the regression results of the board size (DN) variable in Model 1, it can be seen that the size of the board is positively correlated with the credit risk, but it was not statistically significant. The regression coefficient of the independent director ratio (ID) variable in Model 2 was significantly negative at $1 \%$ level. That is, the greater the proportion of independent directors of commercial banks, the smaller the non-performing loan rate, the lower the credit risk. It shows that the independent director system has a strong effect on the credit risk reduction of commercial banks. At the same time, observe the size of the board of supervisors(SN) in the Model 4, which was significantly negative. It shows that the larger the size of the board of supervisors of commercial banks, the lower the credit risk.

Finally, from the regression results of the executive compensation (RE) variable in Model 3,it can be seen that the logarithm of the regression coefficient was significantly negative at $1 \%$ level. It is indicating that the higher the executive compensation, the greater the incentive, the lower the credit risk. Followed by the Model 1 of the management shares (NM) variable regression results, which was also significantly negative. That is, the management of the holdings of commercial banks to reduce the NPL ratio and to reduce the credit risk of commercial banks have a positive effect.

\section{Main conclusions and policy recommendations}

\subsection{Main conclusions}

Based on the internal management mechanism of commercial banks, this paper explores the impact of internal governance mechanism on credit risk of commercial banks through theoretical analysis and empirical analysis using the balance panel data of China's listed commercial banks from 2010 to 2015. Draw the following main conclusions:

From the point of view of ownership concentration, the larger the proportion of the largest shareholder, the higher the NPL ratio, the higher the credit risk of the commercial bank. And the effect of the equity balance degree is not significant. Therefore, for commercial banks, to avoid too much concentration of equity, only the distribution of ownership structure balanced, the constraints between shareholders will be significant. The results of nature of equity show that the stronger the control of commercial banks, the higher the credit risk. This conclusion also confirms the necessity of the reform of China's banking sector.

By observing relationships between credit risk and the board of directors and supervisors, we 
can find that in this paper, the relationship between independent directors and credit risk is very significant. Indicating that with the improvement of the independent director system, its role has become increasingly significant. Besides, the board of supervisors has also played a positive role in the supervision and management of commercial banks.

The results of executive incentive mechanism showed that the better the incentive of commercial banks to executives, the less the NPL ratio and the lower credit risk. Because the incentive mechanism for executives is more significant, it will make the manager more responsible for performance, more prudent in the management. Managers can maximize bank profits while maximizing their own benefits, that is, incentive compatibility constraints.

\subsection{Policy recommendations}

According to the above empirical results and conclusions, this paper puts forward the following policy recommendations to improve the credit risk management ability of listed commercial banks by optimizing the internal governance mechanism from the aspects of equity structure, board of directors and supervisors governance and executive incentive mechanism. Which can be sum up as following: First and foremost, it's necessary to construct the balanced and moderated concentration equity structure, reduce the proportion of state shares and maintain the status of state shares. What's more, it's important to improve the board of supervisors governance and to improve the independence of the board of directors. Last but not least, commercial banks have to promote the management performance evaluation and establish effective incentive mechanism.

\section{References}

1. R. C Anderson, D. R Fraser, Corporate control, bank risk taking, and the health of the banking industry, J. Journal of Banking \& Finance. 8 (2000) 1383-1398.

2. H.B.Liang, Y.L. Liu, Corporate Governance and Credit Risk of Commercial Banks: An Empirical Study Based on Listed Banks, J. Finance and Economics. 10 (2012) 75-78.

3. L.d.S.LaPorta, V. Shleifer, Government Ownership of Commercial Banks, J. Journal of Finance, 57 ( 2002) 265-301.

4. A. Hasan, S. A. Butt, Impact of Ownership Structure and Corporate Governance on Capital Structure of Pakistani Listed Companies, J. International Journal of Business and Management, 2 (2009) 50-57.

5. J.Bonin, Hasan, Bank performance, efficiency and ownership in transition countries, J. Journal of Banking and Finance, 29 (2005) 31-53.

6. Y.H.Li, G.H.He, Corporate Governance and Risk Control of Commercial Banks: Transmission Mechanism and Data Test, J. South China Finance. 5 (2009) 20-25. 